ACTA UNIVERSITATIS WRATISLAVIENSIS

PRZEGLĄD PRAWA I ADMINISTRACJI CXX/2

WROCŁAW 2020

https://doi.org/10.19195/0137-1134.120.58

\author{
KAZIMIERZ J. LEŻAK \\ ORCID: 0000-0003-0038-0245 \\ Uniwersytet Wrocławski \\ Katedra Postępowania Karnego
}

\title{
RACJONALNY SYSTEM WYMIARU KARY ŁĄCZNEJ
}

\begin{abstract}
Abstrakt: W artykule dokonano analizy modelu wymiaru rzeczonej kary pod kątem jego racjonalnego kształtowania w ramach ustawowej regulacji. Celem opracowania uczyniono odpowiedź na pytanie, czy przyjęty przez polskiego ustawodawcę mieszany system wymiaru kary łącznej w obecnym jego kształcie można uznać za racjonalny. W pierwszej kolejności zaprezentowano wypracowane w teorii prawa podstawowe założenia modelu racjonalnego tworzenia prawa. W dalszej części przedstawiono podstawowe założenia kary łącznej w polskim prawie karnym, system wymiaru kary łącznej oraz jego konsekwencje na płaszczyźnie ustawowej regulacji dotyczącej wymiaru kary łącznej. Rozważając, czy system wymiaru kary łącznej jest racjonalny, skonfrontowano postulaty dotyczące racjonalnego tworzenia prawa z kształtowaniem granic wymiaru kary łącznej, w szczególności z możliwością orzekania w wyroku łącznym kary łącznej surowszej niż suma kar podlegających łączeniu.
\end{abstract}

Słowa kluczowe: kara łączna, wyrok łączny, model racjonalnego tworzenia prawa

Truizmem jest stwierdzenie, że system wymiaru kary łącznej winien być racjonalny. To oczywiste stwierdzenie wymaga jednak nieoczywistej już odpowiedzi na niełatwe $\mathrm{w}$ dodatku pytanie o to, $\mathrm{w}$ jaki sposób kształtować ustawowe regulacje dotyczące wymiaru kary łącznej, by uznać, że system wymiaru tej kary jest racjonalny. Udzielenie odpowiedzi jest trudne, gdyż wymaga łącznej analizy zagadnień dotyczących kary łącznej i racjonalności, i nieoczywiste, ponieważ i kara łączna, i racjonalność stanowią zagadnienia złożone, wieloaspektowe i niejednolicie rozwiązywane.

Niemniej jednak korzystając $\mathrm{z}$ dorobku teorii prawa w odniesieniu do zagadnienia racjonalności ${ }^{1}$ oraz teorii i dogmatyki prawa karnego w zakresie problema-

1 W szczególności zob. E. Kustra, Racjonalny ustawodawca. Analiza teoretycznoprawna, Toruń 1980; S. Wronkowska, Problemy racjonalnego tworzenia prawa, Poznań 1982; J. Wróblewski, Teoria racjonalnego tworzenia prawa, Wrocław-Warszawa-Kraków 1985. 
tyki kary łącznej² ${ }^{2}$ możliwa wydaje się analiza modelu wymiaru rzeczonej kary pod kątem jego racjonalnego kształtowania w ramach ustawowej regulacji.

Rozważania będące przedmiotem niniejszego opracowania obejmują zagadnienia odnośnie do modelu racjonalnego tworzenia prawa oraz związane z ustawowym kształtowaniem reguł dotyczących wymiaru kary łącznej w ramach przyjętego przez polskiego ustawodawcę — od samego początku obowiązywania instytucji kary łącznej - mieszanego systemu wymiaru tej kary ${ }^{3}$ przy jednoczesnym uwzględnieniu dualistycznego trybu jej orzekania ${ }^{4}$, znajdujących odzwierciedlenie w kolejnych polskich kodyfikacjach karnych ${ }^{5}$.

2 Przede wszystkim zob. J. Makarewicz, Kodeks karny z komentarzem, Lwów 1938, reprint Lublin 2012; M. Szewczyk, Kara taczna w polskim prawie karnym. Rozważania na tle doktryny i orzecznictwa sadowego, Kraków 1981; D. Kala, Postepowanie w przedmiocie wydania wyroku tacznego. Zagadnienia karnomaterialne i procesowe, Torun 2003; P. Kardas, [w:] System Prawa Karnego, t. 5. Nauka o karze. Sądowy wymiar kary, red. T. Kaczmarek, wyd. 2, Warszawa 2017.

${ }^{3}$ System mieszany wymiaru kary łącznej niekiedy określany jest w literaturze mianem systemu kary łącznej; zob. W. Wróbel, A. Zoll, Polskie prawo karne. Część ogólna, Warszawa 2010, s. 563. Jego istota sprowadza się do wykorzystania, w różnym stopniu i zakresie, znanych w rozmaitych systemach prawnych systemów łączenia kar i ich wykonania, to jest systemu kumulacji absorpcji i asperacji; szerzej na temat poszczególnych systemów łączenia kar i ich aplikacji zob. J. Makarewicz, Polskie prawo karne. Wykład porównawczy z uwzględnieniem prawa obowiąującego w Rzeczypospolitej Polskiej, Lwów-Warszawa 1924, s. 192 n.; W. Wolter, Zarys systemu prawa karnego. Część ogólna, t. 2, Kraków 1934, s. 114 n.; S. Śliwiński, Prawo karne. Materialne. Część ogólna, Warszawa 1946, s. 494 n.; W. Wróbel, A. Zoll, op. cit., s. 562; P. Kardas, [w:] op. cit., s. 578.

${ }^{4}$ Kara łączna od samego początku jej funkcjonowania w polskim porządku prawnym, to jest od jej wprowadzenia do k.k. z 1932 roku, wymierzana jest w dwóch trybach: w trybie jednoczesnego sądzenia oraz w trybie wyroku łącznego. Na temat trybów wymiaru kary łącznej i kontrowersji z ich liczbą na gruncie poszczególnych kodyfikacji karnomaterialnych i karnoprocesowych zob. K.J. Leżak, Tryby wymierzania kary tacznej w perspektywie projektowanych przez Komisje Kodyfikacyjna Prawa Karnego zmian w zakresie przepisów dotyczacych zbiegu przestepstw oraz łączenia kar i środków karnych, „Wrocławskie Studia Sądowe” 2014, nr 2. Por. J. Makarewicz, Kodeks karny..., s. 151-152; L. Peiper, Komentarz do Kodeksu karnego, Kraków 1936, s. 125; motywy ustawodawcze do art. 31 k.k. i 35 k.k. z 1932 roku w: S. Glaser, A. Mogilnicki, Kodeks karny. Komentarz, Kraków 1934, s. 181, 187-189; postanowienie Sądu Najwyższego z dnia 28 października 1931 roku, Zbiór Orzeczeń SN. Orzeczenia Izby Drugiej (Karnej) 1932, z. II, poz. 25; S. Śliwiński, Polski proces karny przed sądem powszechnym. Przebieg procesu i postępowanie wykonawcze, Warszawa 1948, s. 257; Z. Krauze, Glosa do wyroku SN z 6.09.1963 r., IV K 1211/61, „Orzeczenia Sądów Polskich i Komisji Arbitrażowych” (dalej: OSPiKA) 1965, nr 3, s. 134-137; S. Zimoch, Dwie czy trzy sytuacje orzekania kary łącznej, „Nowe Prawo” (dalej: NP) 1972, nr 6, s. 909-914; Z. Kwiatkowski, Istota postępowania o wydanie wyroku tacznego, „Palestra” 1988, nr 8-9, s. 97; S. Stachowiak, Wyrok łaczny w ujęciu kodeksu postępowania karnego, „Prokuratura i Prawo” 1999, nr 11-12, s. 29; T. Grzegorczyk, J. Tylman, Polskie postepowanie karne, Warszawa 2003, s. 918; S. Waltoś, Proces karny. Zarys systemu, Warszawa 2003, s. 567; D. Kala, op. cit., s. 25-37; a także projekt zmian k.k. z 1997 roku w wersji z 5 listopada 2013 roku — tekst z uzasadnieniem, http://bip.ms.gov.pl/pl/dzialalnosc/komisje-kodyfikacyjne/komisja-kodyfikacyjna-prawa-karnego/komisja-kodyfikacyjna-prawa-karnego-2009-2013/ (dostęp: 17.05.2020).

5 Chodzi kolejno o: k.p.k. z 1928 roku, k.k. z 1932 roku, k.k. i k.p.k. z 1969 roku oraz k.k. i k.p.k. z 1997 roku; powoływane dalej w tekście k.k. i k.p.k. bez oznaczenia roku oznaczają k.k. i k.p.k. z 1997 roku.

Przegląd Prawa i Administracji CXX, 2020, cz. 1 i 2

(C) for this edition by CNS 
Celem tego opracowania jest odpowiedź na pytanie, czy przyjęty przez polskiego ustawodawcę mieszany system wymiaru kary łącznej w obecnym jego kształcie można uznać za racjonalny. Jako punkt odniesienia wykorzystano wypracowany w teorii prawa i zrekonstruowany na potrzeby tego artykułu model racjonalnego ustawodawcy.

Uzasadnieniem podejścia do tytułowej tematyki z perspektywy kryteriów racjonalności są, po pierwsze, zmiany w obrębie przepisów regulujących wymiar kary łącznej, dokonywane w kolejnych kodyfikacjach karnych, a w zakresie obowiązującego obecnie k.k. z 1997 roku w ramach nowelizacji dotykających także rozwiązań modelowych orzekania kary łącznej ${ }^{6}$, a wynikających z ustawy z 20 lutego 2015 roku o zmianie ustawy — Kodeks karny oraz niektórych innych ustaw ${ }^{7}$ (która weszła w życie 1 lipca 2015 roku), jak też dalsze zmiany zawarte w uchwalonej już przez Parlament, ale niepodpisanej jeszcze przez Prezydenta RP ustawy z 13 czerwca 2019 roku o zmianie ustawy — Kodeks karny oraz niektórych innych ustaw z uwagi na skierowanie tejże ustawy do Trybunału Konstytucyjnego w celu zbadania jej zgodności z Konstytucją $\mathrm{RP}^{8}$ (przewidujące notabene powrót do pierwotnego modelu orzekania kary łącznej, to jest obowiązującego nieprzerwanie do 1 lipca 2015 roku); po drugie, wypowiedzi Trybunału Konstytucyjnego dotyczące konkretnych przepisów regulujących wymiar kary łącznej, zawarte w wydanych w ostatnim czasie wyrokach, to jest z 22 września 2015 roku w sprawie P 37/149, z 18 kwietnia 2019 roku w sprawie K $14 / 17^{10}$ oraz z 11 czerwca 2019 roku w spra-

${ }^{6}$ W zakresie zmian w obrębie modelu orzekania kary łącznej i ich charakteru zob. P. Kardas, Kara łaczna i ciag przestępstw, [w:] Nowelizacja prawa karnego 2015. Komentarz, red. W. Wróbel, Kraków 2015, s. 449-669.

7 Dz.U. z 2015 r. poz. 396.

${ }^{8}$ Sprawa Kp 1/19 z wniosku Prezydenta RP o zbadanie w całości ustawy z dnia 13 czerwca 2019 roku o zmianie ustawy - Kodeks karny oraz niektórych innych ustaw z art. 7 i art. 112 w związku z art. 119 ust. 1 Konstytucji, 2. art. 3, art. 8 pkt 6 i art. 13 powyższej ustawy z art. 7, art. 118 ust. 1, art. 119 ust. 1 i art. 121 ust. 2 Konstytucji, przez to, że zakres uchwalonych przez Senat poprawek wykroczył poza materię ustawy uchwalonej przez Sejm, 3. art. 1 pkt 37 lit. c), w części obejmującej zmieniany art. $115 \S 19$ ustawy z dnia 6 czerwca 1997 roku — Kodeks karny, w zakresie dotyczącym pkt 4 lit. b) powyższej ustawy z art. 32 ust. 1 Konstytucji, 4. art. 1 pkt 37 lit. c), w części obejmującej zmieniany art. 115 § 19 ustawy z dnia 6 czerwca 1997 roku — Kodeks karny, w zakresie dotyczącym pkt 4 lit. d) powyższej ustawy z art. 42 ust. 1 Konstytucji.

9 Dz.U. z 2015 r. poz. 1528, Legalis nr 1331237. W sprawie tej TK orzekł: „Art. 89 § 1 ustawy z dnia 6 czerwca 1997 r. — Kodeks karny (Dz.U. Nr 88, poz. 553, ze zm.), w brzmieniu obowiązującym do 30 czerwca 2015 r., w zakresie, w jakim pomija możliwość warunkowego zawieszenia wykonania kary łącznej w wypadku orzekania przez sąd o łączeniu warunkowo zawieszonej — na podstawie art. 343 ustawy z dnia 6 czerwca 1997 r. — Kodeks postępowania karnego (Dz.U. Nr 89, poz. 555, ze zm.), w brzmieniu obowiązującym do 30 czerwca 2015 r. — kary pozbawienia wolności w wymiarze wyższym niż 2 lata z karą pozbawienia wolności bez warunkowego zawieszenia jej wykonania, jest niezgodny z art. 45 ust. 1 Konstytucji Rzeczypospolitej Polskiej”.

10 Dz.U. z 2019 r. poz. 858, Legalis nr 1895259. W sprawie tej TK orzekł: „Art. $86 \S 4$ ustawy z dnia 6 czerwca 1997 r. — Kodeks karny (Dz.U. z 2018 r. poz. 1600, ze zm.) w zakresie, w jakim różnicuje sytuacje osób, wobec których zastosowanie miała już wcześniej instytucja kary łącznej, 
wie P 20/1911, odnoszące się do niekonstytucyjności kształtowania konkretnych już reguł wymiaru kary łącznej w zakresie wskazanym w owych wyrokach.

Trzeba także zaakcentować, że czynione w dalszej części artykułu rozważania, z uwagi na rodzaj i zakres niniejszego opracowania, mają charakter jedynie sygnalizacyjny.

Jak już wspomniano, system wymiaru kary łącznej winien być racjonalny. Rzecz jednak w tym, że w literaturze teoretycznoprawnej nie wypracowano jednolitego pojęcia „racjonalności”, gdyż jest ono wieloznaczne, a co za tym idzie stanowiło podstawę do wypracowania wielu różnych koncepcji ${ }^{12}$. W prawoznawstwie racjonalność badana jest w kontekście problemów dotyczących tworzenia, wykładni i stosowania prawa. Te zaś wiążą się z określoną polityką prawa, obejmującą politykę tworzenia prawa, politykę stosowania prawa i politykę realizacji prawa $^{13}$. Skupiając się na płaszczyźnie tworzenia prawa, należy wskazać na wypracowany $\mathrm{w}$ teorii prawa model racjonalnego tworzenia prawa ${ }^{14}$ oraz związane z nim określone rozumienie polityki tworzenia prawa ${ }^{15}$ i jego instrumentalny charakter ${ }^{16}$.

W literaturze teoretycznoprawnej wskazuje się, że polityka tworzenia prawa jest działem polityki prawa, który zajmuje się tworzeniem norm mających służyć realizacji założonych celów ${ }^{17}$. Polityka tworzenia prawa zakłada zatem, że prawo jest rezultatem celowego działania prawodawcy. Prawo jest tu więc pojmowane

od osób, co do których ta instytucja zastosowania nie miała, w ten sposób, że umożliwia w stosunku do tej pierwszej kategorii osób podwyższenie dolnej granicy kary łącznej, a także orzeczenie kary rodzajowo surowszej, tj. kary 25 lat pozbawienia wolności, jest niezgodny z art. 32 ust. 1 Konstytucji Rzeczypospolitej Polskiej".

11 Dz.U. z 2019 r. poz. 1135, Legalis nr 1939775. W sprawie tej TK orzekł: „Art. 87 § 1 ustawy z dnia 6 czerwca 1997 r. — Kodeks karny (Dz.U. z 2018 r. poz. 1600, ze zm.) w zakresie, w jakim nakłada na sąd obowiązek połączenia kar pozbawienia wolności i ograniczenia wolności oraz wymierzenia kary łącznej pozbawienia wolności po dokonaniu zamiany kary ograniczenia wolności na karę pozbawienia wolności, jest niezgodny z art. 45 ust. 1 i art. 175 ust. 1 Konstytucji Rzeczypospolitej Polskiej”.

12 Zob. L. Nowak, Interpretacja prawnicza. Studium z metodologii prawoznawstwa, Warszawa 1973; B. Skarga, Trzy idee racjonalności, „Studia Filozoficzne” 1983, nr 5-6, s. 17-37; J. Wróblewski, op. cit.; L. Morawski, Argumentacje, racjonalność prawa i postępowanie dowodowe, Toruń 1988.

13 J. Wróblewski, op. cit., s. 50-51.

14 Zob. przyp. 12.

15 J. Wróblewski, op. cit., s. 53-59.

$16 \mathrm{Na}$ temat instrumentalnego pojmowania prawa zob. W. Lang, Instrumentalne pojmowanie prawa a państwo prawa, „Państwo i Prawo” (dalej: PiP) 1991, nr 12, s. 3-13.

17 J. Wróblewski, op. cit., s. 50. 
instrumentalnie, to jest jako narzędzie lub środek służący realizacji określonych celów zewnętrznych wobec prawa ${ }^{18}$. Wskazuje się jednocześnie, że podmiot działający celowo opiera się na przyjęciu jakiegoś celu oraz wiedzy co do środków, za pomocą których może ten cel osiągnąć. Jeśli jest tych środków więcej, musi również podjąć decyzję, które z nich należy zastosować. Wiąże się z tym postulat, aby prawo było racjonalne ${ }^{19}$. Przyjmując instrumentalne pojmowanie prawa, konstruuje się postulat racjonalności instrumentalnej prawa ${ }^{20}$. Jest on kierowany do prawodawcy. W konsekwencji, przypisując prawodawcy cechę racjonalności, tworzy się model racjonalnego prawodawcy.

Prawodawca jest racjonalny, jeżeli dobiera właściwe środki dla założonego celu ze względu na wiedzę, jaką dysponuje, i preferencje, jakie przyjmuje. Prawodawca racjonalny po prostu spełnia elementarne warunki wszelkiego racjonalnego celowego działania ${ }^{21}$. Wskazuje się przy tym, że racjonalny prawodawca może działać według polityki tworzenia prawa opartej na założeniach dwojakiego rodzaju. W wersji zwanej „minimalistyczną” prawodawca wybiera wypowiedzi zrelatywizowane instrumentalnie ${ }^{22}$. Z kolei w „maksymalistycznej” wersji polityki tworzenia prawa prawodawca oprócz wypowiedzi zrelatywizowanych instrumentalnie posługuje się wypowiedziami niezrelatywizowanymi lub zrelatywizowanymi systemowo, przy czym relatywizacja systemowa opiera się na założeniu systemu aksjologicznego ${ }^{23}$.

Przedstawione dwa założenia polityki tworzenia prawa odpowiadają podanemu wcześniej instrumentalnemu pojmowaniu prawa, określanemu w literaturze mianem szerokiego. Występuje ono bowiem w dwóch wersjach: redukcjonistycznej i nieredukcjonistycznej. W wersji redukcjonistycznej prawo ma charakter instrumentalny $\mathrm{w}$ tym znaczeniu, że normy i przepisy prawne interpretowane są jako dyrektywy instrumentalne lub celowościowe, w których najwyższą wartością prawa i jedynym relewantnym standardem oceny prawa jest jego skuteczność finistyczna ${ }^{24}$. Wersja nieredukcjonistyczna zaś nie zakłada redukcji norm i przepisów prawnych do dyrektyw instrumentalnych i celowościowych. Obok ocen instrumentalnych czy celowościowych podlegają one ocenom aksjologicznym,

18 W. Lang, op. cit., s. 3. Trzeba jednocześnie wskazać, że instrumentalne pojmowanie prawa nie jest powszechnie akceptowane. Alternatywą jest tu nieinstrumentalne pojmowanie prawa w różnych wersjach; szerzej zob. W. Lang, op. cit., s. 5-7; W. Gromski, Zagadnienie granic instrumentalizacji prawa, [w:] Z zagadnień teorii i filozofii prawa. Instrumentalizacja prawa, red. A. Kozak, Wrocław 2000, s. 76-90.

19 J. Wróblewski, op. cit., s. 52.

20 Por. F. Ciepły, Paradygmat założenia racjonalnej reakcji karnej, [w:] Racjonalna sankcja karna w systemie prawa, red. P. Góralski, A. Muszyńska, Warszawa 2019, s. 27-30.

21 J. Wróblewski, op. cit., s. 60.

22 Ibidem, s. 53.

23 Ibidem, s. 53-54.

24 W. Lang, op. cit., s. 3. 
a także uzasadnieniu tetycznemu. Tym samym skuteczność finistyczna prawa to nie jedyna wartość porządku prawnego ${ }^{25}$.

Jak już wskazano, jednym z podstawowych elementów modelu racjonalnego prawodawcy jest określenie celu, czyli pewnego stanu rzeczy, który prawodawca chce lub powinien osiągnąć. Aby prawodawca był racjonalny, cel musi mieć wartość, czyli znajdować uzasadnienie w przyjętym systemie aksjologicznym ${ }^{26}$. Aksjologia odgrywa ponadto i tę rolę, że wyznacza prawodawcy wybór celu w połączeniu z oceną istniejącego stanu rzeczy. Ów istniejący stan rzeczy może prowadzić do oceny zasadności ustanowienia regulacji prawnej z uwagi na to, że jej nie ma, a powinna być, lub też że istniejąca regulacja daje złe rezultaty lub nie jest dostatecznie skuteczna ${ }^{27}$.

Wybierając z kolei środek do realizacji celu, racjonalny prawodawca winien kierować się dwojakiego rodzaju kryteriami. Po pierwsze, kryteriami prakseologii instrumentalnej, wskazującymi najskuteczniejszy ze środków, jakimi dysponuje prawodawca do osiągnięcia przyjętego celu — wówczas możemy mówić o racjonalności prakseologicznej prawodawcy. Po drugie, racjonalny prawodawca może dokonywać wyboru środków przy przyjęciu nieinstrumentalnych ocen zasadniczych, sprowadzających się do oceny określonych zachowań i ich efektów z przyjętym systemem aksjologicznym ${ }^{28}$. Będzie to z kolei racjonalność aksjologiczna prawodawcy.

Cele racjonalnego prawodawcy nie zmierzają zatem jedynie do osiągnięcia konkretnego stanu rzeczy lub nie są określane li tylko ze względu na daną wartość istniejącego stanu rzeczy, ale wymagają ponadto odwołania się do systemu wartości (aksjologii), które ustawodawca preferuje. Z kolei spośród środków do realizacji owych celów racjonalny ustawodawca wybiera te, które są najbardziej adekwatne, czyli takie, które spełniają dwa warunki: są adekwatne do osiągnięcia zakładanego stanu rzeczy i jednocześnie są zgodne z przyjętym systemem wartości (aksjologią) ${ }^{29}$. Innymi słowy, przy wyborze środka do celu prawodawca winien być racjonalny aksjologicznie. Implikuje to zachowanie się prawodawcy w wypadku kolizji rezultatów oceny instrumentalnej i aksjologicznej danego środka. W przypadku niezgodności najskuteczniejszego środka z przyjętą przez prawodawcę aksjologią, winien on kierować się postulatem wynikającym z racjonalności aksjologicznej, nie zaś płynących z postulatów racjonalności instrumentalnej ${ }^{30}$.

W literaturze zauważa się przy tym, że proces doboru środków do założonych celów może mieć charakter dynamiczny. Realizując określone cele, prawodawca

25 Ibidem, s. 4.

26 J. Wróblewski, op. cit., s. 135, 141.

27 Ibidem, s. 142.

28 Ibidem, s. 147-148.

29 Por. K. Wojtyczek, Granice ingerencji ustawodawczej w sferę praw człowieka w Konstytucji $R P$, Kraków 1999, s. 137.

30 J. Wróblewski, op. cit., s. 148. 
wykorzystuje wiedzę na temat najbardziej adekwatnych środków do ich realizacji i nie stanowi przepisów, które są niecelowe lub bezcelowe. W takiej sytuacji może starać się zmodyfikować cele w taki sposób, aby zaistniały środki prawne do ich realizacji. Oznacza to modyfikację celu ze względu na potencjalne, skuteczne środki prawne. Dochodzi tu do interferencji celów i środków, w następstwie czego to środek wyznaczałby cel, a nie odwrotnie ${ }^{31}$.

W literaturze przedmiotu podnosi się w rezultacie, że model racjonalnego tworzenia prawa określa implicite, kiedy decyzja prawotwórcza jest racjonalna. Przy czym wyróżnia się tu racjonalność wewnętrzną i zewnętrzną. Tworzenie prawa jest wewnętrznie racjonalne, jeżeli znajduje uzasadnienie w świetle wiedzy i preferencji przyjmowanych przez prawodawcę. Z kolei tworzenie prawa jest racjonalne zewnętrznie, gdy przesłanki, które je uzasadniają, podane przez prawodawcę (a wynikające $\mathrm{z}$ jego wiedzy i preferencji), są uznane za trafne przez oceniającego z punktu widzenia jego wiedzy i przyjmowanych przez niego wartości ${ }^{32}$ (z perspektywy zewnętrznej; przez zewnętrznego obserwatora ${ }^{33}$ ). Innymi słowy, racjonalne zewnętrznie tworzenie prawa ma miejsce, gdy decyzja prawodawcy w tym zakresie, podjęta na podstawie przesłanek ją uzasadniających (mających oparcie w wiedzy prawodawcy i preferowanych przez niego wartościach), oceniona zostanie jako trafna według wiedzy oraz aksjologii przyjmowanej przez zewnętrznego obserwatora. Co istotne, zgodność w obu zakresach, to jest między wiedzą i aksjologią prawodawcy oraz zewnętrznego obserwatora, kwalifikuje decyzję prawodawczą jako zewnętrznie racjonalną, niezgodność — jako zewnętrznie nieracjonalną. Jeśli zaś oceniający podmiot zewnętrzny nie jest w stanie przypisać decyzji prawodawczej żadnych uzasadnień, a prawodawca ich nie sformułował, decyzja na płaszczyźnie tworzenia prawa jest wprost irracjonalna ${ }^{34}$.

$\mathrm{Z}$ postulatu racjonalności zewnętrznej tworzenia prawa wynika racjonalność aksjologiczna. Wymaga ona dokonania oceny założonych celów i wyboru środków ich realizacji nie tylko z perspektywy ich skuteczności (racjonalności instrumentalnej), lecz także z uwzględnieniem preferowanego systemu aksjologicznego. W kontekście preferencji aksjologicznych jako kryterium oceny racjonalności zewnętrznej tworzenia prawa w literaturze wskazuje się, że owych wartości i ich preferencji, do których odwołuje się zewnętrzny podmiot oceniający, a także zasad rozstrzygania konfliktów konkurujących z sobą wartości, należy poszukiwać w konkretnym systemie prawa ${ }^{35}$. Tym źródłem wartości, ich preferencji i sposobu rozstrzygania konfliktów między poszczególnymi wartościami jest obecnie Konstytucja ${ }^{36}$.

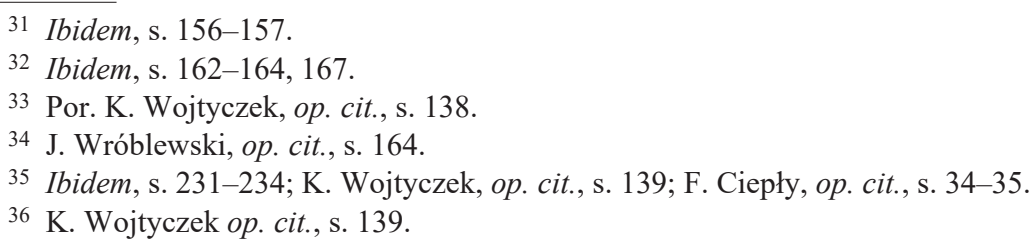


Reasumując, należy wskazać, że na płaszczyźnie tworzenia prawa decyzję prawotwórczą polegającą na stanowieniu prawa można uznać za racjonalną, jeśli pozostaje ona $\mathrm{w}$ zgodzie $\mathrm{z}$ postulatami racjonalności zewnętrznej, uwzględniającej nie tylko postulat racjonalności instrumentalnej, ale jednocześnie realizuje postulaty racjonalności aksjologicznej, przyjmującej za punkt odniesienia system wartości wyrażony i preferowany w Konstytucji, której efektem będzie zgodność stanowionych aktów prawnych z konstytucyjnym systemem aksjologicznym ${ }^{37}$.

W nauce prawa karnego kara łączna postrzega jest jako jedna $\mathrm{z}$ form integracji działalności przestępczej sprawcy ${ }^{38}$, będąca mechanizmem o charakterze redukcyjnym, lokowanym na płaszczyźnie konsekwencji związanych z przypisaniem odpowiedzialności za wiele czynów popełnionych przez tego samego sprawcę $e^{39}$. Redukcyjność kary łącznej polega na wymierzeniu jednej zintegrowanej kary, podlegającej następnie wykonaniu. Mechanizm redukcyjny zaś sprowadza się do zastąpienia wielości orzeczonych za wielość przestępstw kar jedną zintegrowaną karą łączną, która następnie podlega wykonaniu ${ }^{40}$.

Kara łączna jako mechanizm redukcyjny skutkuje określonymi efektami redukcyjnymi, zależnymi od przyjętego jednego z czterech wyróżnianych systemów łączenia kar. Mianowice, systemu kumulacji, absorpcji, asperacji kar oraz systemu mieszanego, występującego w dwóch odmianach — redukcyjnej lub z wykorzystaniem elementów asperacji ${ }^{41}$. W literaturze karnistycznej wskazuje się, że mechanizm redukcyjny w wypadku kary łącznej nie ma charakteru jednolitego. Jest to związane z przyjętym w polskim prawie karnym modelem wymiaru kary

37 Por. ibidem.

38 Kategorię „form integracji działalności kryminalnej tej samej osoby” wprowadził M. Cieślak jako zbiór różnych instytucji prawa karnego materialnego służących ujednoliceniu prawnokarnych konsekwencji przestępczej działalności tej samej osoby; zob. idem, Polskie prawo karne. Zarys systemowego ujęcia, Warszawa 1995, s. 391-417. Koncepcję tę podjął i kontynuuje, lokując w jej ramach i omawiając określone tak zwane mechanizmy redukcyjne, P. Kardas, [w:] System Prawa Karnego, t. 4. Nauka o przestępstwie. Wytaczenie i ograniczenie odpowiedzialności karnej, red. L.K. Paprzycki, Warszawa 2013, s. 878 n. Zob. też A. Wojtaszczyk, Mechanizmy racjonalizacji odpowiedzialności karnej polegającej na sumowaniu działalności przestępczej sprawy a instytucja kary łacznej, [w:] Zagadnienia teorii i nauczania prawa karnego. Kara łączna. Księga jubileuszowa Profesor Marii Szewczyk, red. W. Górowski et al., Warszawa 2013, s. 428-443.

$39 \mathrm{Na}$ temat mechanizmów redukcyjnych na poszczególnych szczeblach prawnokarnego wartościowania zob. P. Kardas, [w:] System Prawa Karnego, t. 4, s. 863-884.

40 Ibidem, s. 868.

41 Szerzej na temat poszczególnych systemów łączenia kar zob. J. Makarewicz, Polskie prawo karne..., s. 192 n.; W. Wolter, op. cit., s. 114 n.; S. Śliwiński, op. cit., s. 494 n.; W. Wróbel, A. Zoll, op. cit., s. 562; P. Kardas, [w:] System Prawa Karnego, t. 5, s. 578. 
łącznej, opartym na systemie mieszanym ${ }^{42}$. Zakłada on wykorzystanie w różnym stopniu systemu: kumulacji, absorpcji i asperacji. Jednocześnie mieszany model wymiaru kary łącznej powoduje, że mechanizm redukcyjny może prowadzić do trojakiego rodzaju efektów redukcyjnych:

— czystej redukcji przy wymierzaniu kary łącznej na zasadzie absorpcji (co odpowiada systemowi absorpcji);

— integracji połączonej z częściową kumulacją w razie wykorzystania przy wymierzaniu kary łącznej zasady asperacji (co odpowiada systemowi aperacji);

— integracji połączonej z kumulacją, gdy wymiar kary łącznej opiera się na zasadzie kumulacji ${ }^{43}$ (co odpowiada systemowi kumulacji).

Dodać należy, że kara łączna zastępuje wielość kar orzeczonych za wielość przestępstw tego samego sprawcy w ramach tego samego postępowania (gdy jest orzekana $\mathrm{w}$ ramach jednego postępowania i wyroku), a także zastępuje wielość kar orzeczonych wobec tego samego sprawcy w wielu wydanych wobec niego prawomocnych wyrokach (gdy jest orzekana w trybie wyroku łącznego). Mechanizm redukcyjny w postaci kary łącznej może zatem dotyczyć integracji zarówno wielości nieprawomocnie orzeczonych, jak i wielości prawomocnie orzeczonych już kar, przekształcając ową wielość kar w jedną karę łączną, skutkującą określonym, jednym $z$ wymienionych, efektem redukcyjnym.

W scharakteryzowanym wyżej mieszanym modelu wymiaru kary łącznej efekt uzyskany w razie zastosowania mechanizmu redukcyjnego, jakim jest kara łączna, powoduje integrację połączoną $\mathrm{z}$ absorbcją, asperacją, a w najgorszym razie - z kumulacją. W rezultacie zastosowanie omawianego mechanizmu redukcyjnego może ostatecznie nie wpłynąć na sytuację prawną sprawcy, która nie ulegnie zmianie w porównaniu z sytuacją, jaka miałaby miejsce, gdyby go nie zastosowano. Orzeczenie kary łącznej jako mechanizmu redukcyjnego w żadnym razie nie prowadzi natomiast - po jego zaaplikowaniu — do efektu w postaci integracji połączonej z progresją, co ma miejsce, gdy wymiar kary łącznej swą dolegliwością przekracza poziom dolegliwości wynikający z systemu kumulacji (zarówno pod względem ilościowym, jak i jakościowym). Mechanizm redukcyjny, którego elementem jest kara łączna, nie prowadzi także — w swych założeniach — do efektu w postaci integracji i inkorporacji, co ma z kolei miejsce, gdy wymiar kary łącznej - niezależnie od tego, czy opiera się na zasadzie absorpcji, asperacji, czy kumulacji — inkorporuje nadto elementy nowe, nieistniejące przed redukcją.

Tak kształtowany mieszany model wymiaru kary łącznej opiera się na określonym uzasadnieniu funkcjonowania instytucji kary łącznej i pociąga za sobą konsekwencje na płaszczyźnie ustawowej regulacji dotyczącej jej wymiaru.

${ }^{42}$ W. Wróbel, A. Zoll, op. cit., s. 562-563. Na temat rodzajów modeli łączenia kar i ich charakterystykę zob. P. Kardas, [w:] System Prawa Karnego, t. 5, s. 578.

${ }^{43}$ P. Kardas, [w:] System Prawa Karnego, t. 4, s. 868. 
Wybitny przedstawiciel polskiej nauki prawa karnego, prof. J. Makarewicz, już w 1914 roku wskazywał, że tendencją ustawy jest zastosowanie kary wspólnej dla zbiegających się przestępstw, a mianowicie łagodniejszej od sumy kar, które sprawcy należałoby wymierzyć ${ }^{44}$. Autor zauważał jednocześnie, że tendencją ustawodawstwa jest także to, aby uwzględniać fakt, że sprawca dotychczas za żadne ze zbiegających się przestępstw nie poniósł jeszcze kary. Dlatego też z natury rzeczy na równi z czystym zbiegiem należy traktować przypadek, kiedy przestępstwa nie są przedmiotem tego samego postępowania i wyroku. Sama zaś okoliczność, że przestępstwa te nie wyszły na jaw równocześnie, nie może bowiem mieć niekorzystnego wpływu na sytuację sprawcy ${ }^{45}$. Poglądy J. Makarewicza na zagadnienia związane ze zbiegiem przestępstw i wspólną dla kar wymierzonych za zbiegające się przestępstwa karę łączną znalazły następnie odzwierciedlenie w przepisach kodeksu karnego z 1932 roku, które przede wszystkim regulowały wymierzenie kary łącznej w razie jednoczesnego skazania sprawcy dwóch lub więcej pozostających w zbiegu przestępstw, której podstawę stanowiły kary wymierzone za poszczególne przestępstwa, normując nadto przesłanki, zasady i granice wymiaru tej kary (art. 31-34 k.k. z 1932 roku). Jak wyjaśniał J. Makarewicz, kara łączna jest faworyzowaniem skazanego, gdyż uchyla mechaniczną kumulację, a tym samym jest zbędna tam, gdzie kumulacja nie grozi ${ }^{46}$. Ponadto k.k. z 1932 roku $\mathrm{w}$ art. 35 rozciągnął zastosowanie przepisów regulujących podstawy, przesłanki, zasady i granice wymiaru kary łącznej orzekanej w ramach jednoczesnego sądzenia na przypadki niejednoczesnego sądzenia, gdy sprawca został skazany kilkoma prawomocnymi wyrokami za przestępstwa popełnione przed wydaniem przez sąd pierwszej instancji pierwszego z tych wyroków. Przy czym przepisy te były stosowane „odpowiednio”. Wówczas dochodziło do wydania wyroku łącznego z uwzględnieniem treści art. 32 k.p.k. z 1928 roku$^{47}$. Komentując treść art. 35 k.k. z 1932 roku, J. Makarewicz wskazywał, że przepis ten stwarza podobieństwo do sytuacji z art. 31, tak jakby wszystkie przestępstwa były przedmiotem jednoczesnego osądzenia ${ }^{48}$, zadaniem zaś kary łącznej jest uproszczenie postępowania wykonawczego i zapobieżenie nadmiernej surowości, wynikającej z czystej kumulacji kar, z jednoczesnym zastrzeżeniem, że kara ta nie ma na celu zupełnego przekreślenia faktu historycznego popełnienia większej liczby czynów karygodnych ${ }^{49}$. Symptomatyczne jest, że ową sytuację procesową, będącą podstawą kary łącznej orzekanej w wyroku łącznym, zarówno ustawodawca ${ }^{50}$, jak i dogmatycy

44 J. Makarewicz, Prawo karne ogólne, Kraków 1914, s. 191.

45 Ibidem, s. 195.

46 J. Makarewicz, Kodeks karny..., s. 147.

47 Pierwotnie był to art. 30 k.p.k. z 1928 roku.

48 J. Makarewicz, Kodeks karny..., s. 158-159.

49 Ibidem, s. 159.

50 Zob. S. Glaser, A. Mogilnicki, op. cit., s. 188 w odniesieniu do uzupełnieniu motywów ustawodawczych do art. 35 k.k. z 1932 roku. 
prawa $^{51}$ nazywali ówcześnie fikcją zbiegu przestępstw (tak zwanym fikcyjnym zbiegiem realnym). W rezultacie do polskiego porządku prawnego wprowadzono dwa tryby wymierzenia kary łącznej, przewidziane dla dwóch odmiennych układów procesowych, spośród których ten będący trybem wyroku łącznego został oparty na „odpowiednim” stosowaniu normatywnych reguł wyznaczających podstawy, przesłanki, zasady i granice wymiaru kary łącznej w trybie jednoczesnego sądzenia, przy równoczesnym spełnianiu przez tę karę tożsamych celów i zadań, niezależnie od zastosowanego trybu jej wymiaru.

„Odpowiednie" stosowanie do wymiaru kary łącznej orzekanej w wyroku łącznym reguł wyznaczających podstawy, przesłanki, zasady i granice wymiaru kary łącznej w trybie jednoczesnego sądzenia na gruncie k.k. z 1932 roku determinowało wiele konsekwencji, między innymi w określaniu górnej granicy kary łącznej w wyroku łącznym. Mianowicie, dominował pogląd o wykonawczym charakterze kary łącznej. Takie ujęcie charakteru kary łącznej wiązało się z przyjęciem celu tej kary, którym było zapobieganie prostej kumulacji kar. Nacisk kładziono na aspekt gwarancyjny przy kształtowaniu granic kary łącznej w oparciu o kary już wymierzone, $\mathrm{z}$ jednoczesnym określeniem specyficznego ustawowego minimum i maksimum kary łącznej. Jednocześnie zakres swobody sędziego przy wymiarze kary łącznej ulegał ograniczeniu w toku jej orzekania w wyroku łącznym, gdyż szczególnego znaczenia nabierała kwestia prawomocności, a na pierwszy plan wysuwano zasadę powagi rzeczy osądzonej ${ }^{52}$. Określanie granic wymiaru rzeczonej kary następowało z uwzględnieniem poziomu dolegliwości wynikającego $\mathrm{z}$ odrębnego wykonania poszczególnych prawomocnie orzeczonych kar. Brakowało również możliwości modyfikacji orzeczonych kar, na przykład w zakresie warunkowego zwieszenia czy rodzaju kary ${ }^{53}$.

Na gruncie kolejnych kodyfikacji karnych poglądy na zadania i charakter prawny kary łącznej ulegały ewolucji, co pociągało za sobą także sposób kształtowania reguł wymiaru tej kary. O ile początkowo dominował pogląd, wedle którego celem i zadaniem kary łącznej, niezależnie od trybu jej wymiaru, jest faworyzowanie skazanego przez uchylenie mechanicznej kumulacji i zapobieżenie nadmiernej surowości wynikającej z czystej kumulacji kar, to jednak z czasem, na tle kolejnych kodyfikacji karnomaterialnych i karnoprocesowych, to jest z 1969 i z 1997 roku, zaczęło przeważać stanowisko, wedle którego kara łączna służy do dokonania ostatecznej, całościowej oceny przestępczej działalności sprawcy, obejmującej wszystkie popełnione przez niego przestępstwa. Przyjmowano, że karę łączną należy postrzegać na płaszczyźnie prewencyjnej. Ma być karą celową,

${ }^{51}$ Ibidem, s. 186. Por. J. Makarewicz, Kodeks karny..., s. 157-158.

52 A. Zoll, Charakter prawny kary łacznej, [w:] Zagadnienia teorii..., s. 445.

53 J. Rozenblatt, Rzecz o zbiegu przestepstw (z uwzględnieniem obecnego ustawodawstwa w Europie), Warszawa 1877; J. Makarewicz, Kodeks karny..., s. 158; P. Kardas, [w:] System Prawa Karnego, t. 5, s. 587. 
ma służyć resocjalizacji sprawcy ${ }^{54}$. Ponoszono, że skoro ta nowa kara w formie kary łącznej ma lepiej spełniać swoje cele, to sąd wydający wyrok łączny winien mieć większą swobodę w wymiarze nowej kary łącznej. Ma bowiem dodatkowe informacje, których nie posiadał sąd lub sądy orzekające w wyrokach jednostkowych. W konsekwencji postulowano umożliwienie sądowi wydającemu wyrok łączny orzeczenia na przykład kar dodatkowych, mimo że nie zawierał ich żaden z łączonych wyroków jednostkowych, lub zastąpienie kary innymi środkami oddziaływania ${ }^{55}$.

Podnoszono w konsekwencji, że ani przepisy k.k., ani przepisy k.p.k. nie zawierają zakazu pogarszania sytuacji prawnej sprawcy ${ }^{56}$, w związku z czym wyrok łączny może pogorszyć sytuację skazanego ${ }^{57}$. Wywodzono, że normatywna istota dotycząca regulacji kary łącznej sprowadza się do stworzenia prawnych ram racjonalizacji wymiaru kary w wypadku popełnienia przez tego samego sprawcę dwóch lub więcej przestępstw pozostających w realnym zbiegu ${ }^{58}$, wyrok łączny zaś jest li tylko instytucją realizującą normy prawa materialnego ${ }^{59}$. Wskazywano, że racjonalizacja kary orzekanej jako kara łączna w wyroku łącznym nie musi być jednak rozumiana wyłącznie jako łagodzenie i mieć zatem charakter jednokierunkowy $^{60}$. Nie ma bowiem żadnych przeszkód, aby uznać, że racjonalny ustawodawca świadomie założył, że wymierzenie kary łącznej w pewnych wypadkach może prowadzić do pogorszenia sytuacji skazanego. Co więcej, wywodzono, że nie stoją temu na przeszkodzie standardy ani konstytucyjne, ani określone w ratyfikowanych umowach międzynarodowych chroniących uniwersalne prawa i wolności człowieka ${ }^{61}$.

Obecnie, po zmianach modelowych w obrębie modelu orzekania kary łącznej obowiązujących od 1 lipca 2015 roku, postrzeganie kary łącznej jako celowej nie uległo zmianie. Co więcej, wprowadzono kolejne rozwiązania ustawowe regulujące wymiar kary łącznej, umożliwiające ustalenie stopnia dolegliwości tej kary

${ }^{4}$ M. Szewczyk, op. cit., s. 35. Podobne stanowisko prezentuje K. Buchała, Wymiar kary tacznej, PiP 1972, nr 1, s. 49-61.

55 M. Szewczyk, op. cit., s. 57.

56 Ł. Gramza, Glosa do uchwaty SN z dnia 25 października 2000 r., I KZP 28/00, „Orzecznictwo Sądów Polskich" (dalej: OSP) 2001, nr 9, s. 420; P. Kardas, [w:] Kodeks karny. Część ogólna. Komentarz do art. 1-116 k.k., red. A. Zoll, Warszawa 2012, s. 1077; A. Barczak-Oplustil, Dyrektywy wymiaru kary tacznej, [w:] Zagadnienia teorii..., s. 472.

57 Tak SN w wyroku z dnia 15 października 2008 roku, sygn. IV KK 113/08, LEX nr 469408; czy w wyroku z dnia 14 czerwca 2011 roku, sygn. IV KK 159/11, LEX nr 848159. Zob. też P. Kardas, [w:] Kodeks karny. Komentarz. Część ogólna, t. 2. Komentarz do art. 53-116, red. W. Wróbel, A. Zoll, Warszawa 2016, s. 450.

58 P. Kardas, [w:] Kodeks karny. Komentarz. Część ogólna, t. 2, s. 450.

59 Wyrok SN z dnia 1 grudnia 2004 roku, sygn. IV KK 278/04, LEX nr 141356.

60 D. Wysocki, Glosa do uchwaty SN z 25.10.2000 r., I KPZ 28/00, OSP 2000, nr 3, s. 160; J. Raglewski, Kontrowersje zwiazane z orzekaniem kary łacznej na tle kodeksu karnego, PiP 2003, nr 5, s. 90; wyrok SN z dnia 21 sierpnia 2007 roku, sygn. II KK 96/07, OSNKW 2008, z. 1, poz. 6.

61 Tak SN w wyroku z dnia 1 października 2002 roku, sygn. V KK 73/02, LEX nr 56827. 
dla skazanego na poziomie wyższym niż stopień dolegliwości wynikający z konieczności odrębnego wykonania wszystkich kar wymierzonych prawomocnymi wyrokami.

W kontekście powyższego w najnowszej literaturze karnistycznej dostrzeżono, że kara łączna może być postrzegana jako instytucja redukcyjna na płaszczyźnie ilościowej oraz dolegliwościowej ${ }^{62}$. Pierwsza płaszczyzna wiąże się z redukcją poprzez zastąpienie wielości wymierzonych temu samemu sprawcy kar jedną, zintegrowaną karą łączną. Druga wiąże się natomiast z redukcją poprzez zastąpienie wielości wymierzonych temu samemu sprawcy kar jedną, zintegrowaną karą łączną, której wymiar może wiązać się także ze specyficznym „zwiększeniem” dolegliwości wobec sprawcy pozostających w zbiegu przestępstw ${ }^{63}$.

Posługiwanie się kryterium dolegliwościowym w odniesieniu do modelu łączenia kar i powiązanych z nim rodzajów efektów redukcyjnych, jakie kara łączna może wywołać w następstwie jej wymierzenia, oznacza, że efekty redukcyjne mechanizmu redukcyjnego, jakim jest kara łączna, mogą prowadzić — oprócz integracji połączonej z czystą redukcją na zasadzie absorpcji, przez integrację połączoną z częściową kumulacją przy zastosowaniu zasady asperacji, do integracji i kumulacji przy wykorzystaniu zasady kumulacji — także do integracji połączonej z progresją oraz integracji połączonej z inkorporacją. Wskazuje to, że mieszany model wymiaru kary łącznej, przyjęty w polskich rozwiązaniach karnoprawnych, wyznaczają wywoływane w następstwie orzeczenia tej kary efekty redukcyjne, które z kolei determinują ustawowe regulacje dotyczące wymiaru kary łącznej.

\section{IV}

W celu określenia, czy model wymiaru kary łącznej obowiązujący w polskim prawie karnym jest racjonalny, należy dokonać nie tyle oceny poszczególnych rozwiązań, ile determinujących je dopuszczalnych efektów redukcyjnych skutkujących wymierzeniem kary łącznej.

Jak przyjęto, decyzja prawotwórcza polegająca na stanowieniu prawa jest racjonalna, jeśli pozostaje w zgodzie z postulatami racjonalności zewnętrznej, uwzględniającej nie tylko postulat racjonalności instrumentalnej, lecz jednocześnie realizuje także postulaty racjonalności aksjologicznej, przyjmującej za punkt odniesienia system wartości wyrażony i preferowany w Konstytucji, której efektem będzie zgodność stanowionych aktów prawnych z konstytucyjnym systemem aksjologicznym.

$\mathrm{Z}$ perspektywy postulatu racjonalności instrumentalnej w odniesieniu do kary łącznej efekty redukcyjne kary łącznej w postaci integracji i inkorporacji oraz inte-

62 P. Kardas, Kara taczna..., s. 486.

${ }^{63}$ Ibidem, s. 486-487. 
gracji i progresji są skutecznym środkiem do realizacji celu, jakim w wypadku rzeczonej kary jest orzeczenie kary celowej, stanowiącej podsumowanie przestępczej działalności sprawy. Wskazane efekty redukcyjne uwzględniają fakt, iż sąd ma pełną wiedzę co do zakresu i rodzaju dotychczasowych przestępczych zachowań sprawcy i jednocześnie dają adekwatne instrumenty do uczynienia kary łącznej karą celową. Dodać należy, że skutki owych efektów redukcyjnych ujawniają się wyłącznie w trybie wyrokowania łącznego ${ }^{64}$.

Z perspektywy postulatu racjonalności aksjologicznej należałoby ocenić, czy efekty redukcyjne kary łącznej w postaci integracji i inkorporacji oraz integracji i progresji spełniają kryteria racjonalności aksjologicznej. Innymi słowy, należy ocenić, czy ustawowe regulacje dotyczące wymiaru kary łącznej, opierające się na tych efektach redukcyjnych, pozostają w zgodzie z wartościami wyrażonymi i preferowanymi przez Konstytucję. Wspomniane na wstępie orzeczenia Trybunału Konstytucyjnego dowodzą, że czynienie tego rodzaju ocen nie jest bezzasadne czy niecelowe - wręcz przeciwnie.

Godzi się przede wszystkim podnieść, że już intuicyjnie instytucja kary łącznej ze swej natury ma łączyć. Jest więc efektem połączenia samodzielnych elementów takimi, jakie one są, bez ich modyfikacji, jak też bez dodawania nowych elementów. W przeciwnym razie kara łączna przestaje być efektem łączenia. Niemniej ustawodawca ma prawo stanowić regulacje prawne, które w sposób bardziej skuteczny będą realizowały zakłady cel. Ergo, prawodawca może wprowadzić określone efekty redukcyjne kary łącznej, które lepiej, skuteczniej zrealizują zakładany cel. Co więcej, ów cel jest też wartościowy — wiąże się z osiągnięciem stanu sprawiedliwości materialnej przez zastosowanie trafnej reakcji karnej ${ }^{65}$, co jednocześnie służy zapewnieniu porządku publicznego, $\mathrm{w}$ tym bezpieczeństwa publicznego ${ }^{66}$. Stanowi też realizację zasady równości ${ }^{67}$.

Dalej należy zauważyć, że orzekanie kary łącznej w wyroku łącznym ingeruje w prawomocność wyroków orzekających kary podlegające łączeniu i wynikający ze stanu prawomocności zakaz ne bis in idem. To zaś wymaga oceny dopuszczal-

${ }^{64}$ Jest tak, ponieważ w trybie jednoczesnego sądzenia poziom dolegliwości kary łącznej kształtuje się dopiero w następstwie uprawomocnienia się wyroku. Natomiast w trybie wyrokowania łącznego już istnieje określony poziom dolegliwości, wynikający z prawomocnych wyroków jednostkowych wydanych do tej pory wobec skazanego.

65 Por. A. Sakowicz, Zasada ne bis in idem w prawie karnym w ujęciu paneuropejskim, Białystok 2011, s. 52.

${ }^{66} \mathrm{~W}$ literaturze przyjmuje się, że w zakres klauzuli ograniczającej prawa i wolności w postaci „porządku publicznego” wchodzi także bezpieczeństwo publiczne; zob. K. Wojtyczek, op. cit., s. $184-190$.

67 Zob. J. Makarewicz, Kodeks karny..., s. 157; S. Glaser, Polskie prawo karne w zarysie, Kraków 1933, s. 300; W. Wolter, op. cit., s. 115; F.y., Czy można wyrokiem łacznym objać wyrok zawieszajacy wykonanie kary pozbawienia wolności?, „Przegląd Sądowy” 12, 1936, nr 12, s. 393; S. Śliwiński, op. cit., s. 494; J. Pozorski, Z problematyki kary łącznej w wyroku łącznym, NP 1966, nr 1, s. 18-19. 
ności tego trybu jako wyjątku od zasady ne bis in idem, zakazującej ponownego ścigania i karania tej samej osoby za to samo. Ponadto trzeba uwzględnić taką wartość jak prawo do wiążącego rozstrzygnięcia sądowego, będące elementem prawa do sądu.

Pojawia się tutaj konflikt między materialnoprawnymi regułami wymiaru kary łącznej, wyznaczającymi zakres dopuszczalnych efektów redukcyjnych, jakie orzeczenie tej kary w wyroku łącznym może wywołać na płaszczyźnie jej dolegliwości dla skazanego, a procesowymi zasadami, wynikających z umiejscowienia postępowania o wyrok łączny w strukturze procesu karnego, w szczególności z zasadą ne bis in idem, wynikającą ze stanu prawomocności materialnej w odniesieniu do prawomocnych wyroków jednostkowych.

Przyjmując, że prawomocność i związana z nią zasada ne bis in idem mają charakter gwarancyjny, chroniący jednostkę przed ingerencją w jej prawa i wolności, oraz przyjmując, że kara łączna poprzez określone reguły jej wymiaru jest formą ingerencji w owe prawa i wolności jednostki, otworzyła się perspektywa rozstrzygnięcia dopuszczalności progresji dolegliwości kary łącznej na płaszczyźnie jej wymiaru przez dopuszczenie efektów redukcyjnych w postaci integracji i progresji oraz integracji i inkorporacji. Możliwość tę daje zastosowanie zasady proporcjonalności, określającej warunki dopuszczalnej ingerencji w prawa i wolności jednostki. Ponieważ chroni je zakaz ne bis in idem, miarą dopuszczalności jego przełamania, na zasadzie wyjątku od zakazu ponownego ścigania i karania za to samo, jest spełnienie przez reguły wymiaru kary łącznej wymogów niezbędności, konieczności i proporcjonalności sensu stricto.

Realizacja wartości leżących u podstaw ukształtowania reguł wymiaru kary łącznej w wyroku łącznym, które wiążą się z wywoływanymi przez orzeczenie kary łącznej efektami redukcyjnymi, polegającymi na integracji i inkorporacji lub integracji progresji dolegliwości, stanowi nieproporcjonalne ograniczenie wartości związanych z obowiązywaniem zakazu ne bis in idem. Preferencja realizacji zasady sprawiedliwości materialnej, wyrażającej się w dokonaniu trafnej reakcji karnej, która może prowadzić do zwiększenia faktycznej dolegliwości kary jedynie w trybie wyrokowania łącznego, godzi w zasadę równości. Prowadzi także do destabilizacji prawomocnych orzeczeń sądowych, przez co pozbawia ukształtowany w wyniku ich wydania stan prawny jakiegokolwiek znaczenia. Ponadto ogranicza prawo do wiążącego rozstrzygnięcia sądowego w takim stopniu, że prowadzi do naruszenia istoty tego prawa, a tym samym narusza istotę prawa do sądu ${ }^{68}$.

Mając na uwadze wynik ważenia wartości na podstawie konstytucyjnego testu proporcjonalności, należy stwierdzić, że ustawodawca racjonalny będzie dążył do stanowienia takiego prawa, które będzie odpowiadało postulatowi racjonalno-

68 Szerzej zob. K.J. Leżak, „Korzystność” wyroku tącznego. Analiza pogladów doktryny i orzecznictwa sądowego na tle polskich rozwiąań normatywnych, niepublikowana rozprawa doktorska, Uniwersytet Wrocławski, Wrocław 2019. 
ści aksjologicznej. Jeśli wynikiem konfliktu wartości jest preferencja tych, które wiążą się z zasadą ne bis in idem, przyjęty w polskim prawie karnym mieszany system wymiaru kary łącznej nie może opierać się na efektach redukcyjnych w postaci integracji i inkorporacji oraz integracji i progresji. Eliminując wskazane efekty redukcyjne kary łącznej, ustawodawca, stanowiąc konkretne przepisy prawne, będące realizacją pozostałych efektów redukcyjnych, to jest integracji połączonej z czystą redukcją na zasadzie absorpcji, integracji połączonej z częściową kumulacją przy zastosowaniu zasady asperacji oraz integracji i kumulacji przy wykorzystaniu zasady kumulacji, pozostanie w zgodzie z postulatami racjonalności aksjologicznej, ergo — zarówno ustawodawca, jak i przyjęty przez niego system wymiaru kary będą racjonalne.

\title{
RATIONAL SYSTEM OF INFLICTING AGGREGATE PENALTY
}

\author{
Summary
}

The aim of the article is to answer the question whether the mixed system of aggregate penalty adopted by the Polish legislator in its current form can be considered rational. Firstly, the basic assumptions of the model of rational law creation developed in the theory of law were presented. Secondly, the basic assumptions of the aggregate penalty in Polish criminal law were discussed, as well as the aggregate penalty system and its consequences at the level of statutory regulation regarding the aggregate penalty. When considering whether the system of imposing an aggregate penalty is rational, the expectations regarding rational lawmaking were confronted with the statutory limits of the imposition of an aggregate penalty, in particular with the possibility of inflicting in an aggregate sentence an aggregate penalty more severe than the sum of the penalties subject to merger.

Keywords: aggregate penalty, aggregate sentence, model of rational law-making

\section{BIBLIOGRAFIA}

Barczak-Oplustil A., Dyrektywy wymiaru kary łacznej, [w:] Zagadnienia teorii i nauczania prawa karnego. Kara łączna. Księga jubileuszowa Profesor Marii Szewczyk, red. W. Górowski, P. Kardas, T. Sroka, W. Wróbel, Warszawa 2013.

Buchała K., Wymiar kary łącznej, „Państwo i Prawo” 1972, nr 1.

Ciepły F., Paradygmat założenia racjonalnej reakcji karnej, [w:] Racjonalna sankcja karna w systemie prawa, red. P. Góralski, A. Muszyńska, Warszawa 2019.

Cieślak M., Polskie prawo karne. Zarys systemowego ujęcia, Warszawa 1995.

F.y., Czy można wyrokiem łącznym objać wyrok zawieszający wykonanie kary pozbawienia wolności?, „Przegląd Sądowy” 12, 1936, nr 12.

Glaser S., Mogilnicki A., Kodeks karny. Komentarz, Kraków 1934.

Gramza Ł., Glosa do uchwały SN z dnia 25 października 2000 r., I KZP 28/00, „Orzecznictwo Sądów Polskich" 2001, nr 9.

Gromski W., Zagadnienie granic instrumentalizacji prawa, [w:] Z zagadnień teorii i filozofii prawa. Instrumentalizacja prawa, red. A. Kozak, Wrocław 2000. 
Grzegorczyk T., Tylman J., Polskie postępowanie karne, Warszawa 2003.

Kala D., Postępowanie w przedmiocie wydania wyroku tacznego. Zagadnienia karnomaterialne i procesowe, Torun 2003.

Kardas P., [w:] Kodeks karny. Część ogólna. Komentarz do art. 1-116 k.k., red. A. Zoll, Warszawa 2012.

Kardas P., [w:] System Prawa Karnego, t. 4. Nauka o przestępstwie. Wyłaczenie i ograniczenie odpowiedzialności karnej, red. L.K. Paprzycki, Warszawa 2013.

Kardas P., [w:] System Prawa Karnego, t. 5. Nauka o karze. Sadowy wymiar kary, red. T. Kaczmarek, wyd. 2, Warszawa 2017.

Kardas P., Kara taczna i ciag przestęstw, [w:] Nowelizacja prawa karnego 2015. Komentarz, red. W. Wróbel, Kraków 2015.

Krauze Z., Glosa do wyroku SN z 6.09.1963 r., IV K 1211/61, „Orzecznictwo Sądów Polskich i Komisji Arbitrażowych" 1965, nr 3.

Kustra E., Racjonalny ustawodawca. Analiza teoretycznoprawna, Torun 1980.

Kwiatkowski Z., Istota postępowania o wydanie wyroku łącznego, „Palestra” 1988, nr 8-9.

Lang W., Instrumentalne pojmowanie prawa a państwo prawa, „Państwo i Prawo” 1991, nr 12.

Leżak K.J., „Korzystność” wyroku łącznego. Analiza pogladów doktryny i orzecznictwa sądowego na tle polskich rozwiazań normatywnych, niepublikowana rozprawa doktorska, Uniwersytet Wrocławski, Wrocław 2019.

Leżak K.J., Tryby wymierzania kary tacznej w perspektywie projektowanych przez Komisję Kodyfikacyjna Prawa Karnego zmian w zakresie przepisów dotyczacych zbiegu przestępstw oraz taczenia kar i środków karnych, „Wrocławskie Studia Sądowe” 2014, nr 2.

Makarewicz J., Kodeks karny z komentarzem, Lwów 1938, reprint Lublin 2012.

Makarewicz J., Polskie prawo karne. Wykład porównawczy z uwzględnieniem prawa obowiązującego w Rzeczypospolitej Polskiej, Lwów-Warszawa 1924.

Makarewicz J., Prawo karne ogólne, Kraków 1914.

Morawski L., Argumentacje, racjonalność prawa i postępowanie dowodowe, Toruń 1988.

Nowak L., Interpretacja prawnicza. Studium z metodologii prawoznawstwa, Warszawa 1973.

Peiper L., Komentarz do Kodeksu karnego, Kraków 1936.

Pozorski J., Z problematyki kary łacznej w wyroku łacznym, „Nowe Prawo” 1966, nr 1.

Raglewski J., Kontrowersje związane z orzekaniem kary łącznej na tle kodeksu karnego, „Państwo i Prawo" 2003, nr 5.

Rozenblatt J., Rzecz o zbiegu przestępstw (z uwzględnieniem obecnego ustawodawstwa w Europie), Warszawa 1877.

Sakowicz A., Zasada ne bis in idem w prawie karnym w ujęciu paneuropejskim, Białystok 2011.

Skarga B., Trzy idee racjonalności, „Studia Filozoficzne” 1983, nr 5-6.

Stachowiak S., Wyrok łączny w ujęciu kodeksu postępowania karnego, „Prokuratura i Prawo” 1999, nr $11-12$

Szewczyk M., Kara łączna w polskim prawie karnym. Rozważania na tle doktryny i orzecznictwa sądowego, Kraków 1981.

Śliwiński S., Polski proces karny przed sądem powszechnym. Przebieg procesu i postępowanie wykonawcze, Warszawa 1948.

Śliwiński S., Prawo karne. Materialne. Część ogólna, Warszawa 1946.

Waltoś S., Proces karny. Zarys systemu, Warszawa 2003.

Wojtyczek K., Granice ingerencji ustawodawczej w sferę praw człowieka w Konstytucji RP, Kraków 1999.

Wojtaszczyk A., Mechanizmy racjonalizacji odpowiedzialności karnej polegającej na sumowaniu działalności przestępczej sprawy a instytucja kary łącznej, [w:] Zagadnienia teorii i nauczania prawa karnego. Kara łączna. Księga jubileuszowa Profesor Marii Szewczyk, red. W. Górowski, P. Kardas, T. Sroka, W. Wróbel, Warszawa 2013. 
Wolter W., Zarys systemu prawa karnego. Część ogólna, t. 2, Kraków 1934.

Wronkowska S., Problemy racjonalnego tworzenia prawa, Poznań 1982.

Wróblewski J., Teoria racjonalnego tworzenia prawa, Wrocław-Warszawa-Kraków-Gdańsk-Łódź 1985.

Wróbel W., Zoll A., Polskie prawo karne. Część ogólna, Warszawa 2010.

Wysocki D., Glosa do uchwały SN z 25.10.2000 r., I KPZ 28/00, „Orzecznictwo Sądów Polskich” $2000, \mathrm{nr} 3$.

Zimoch S., Dwie czy trzy sytuacje orzekania kary łacznej, „Nowe Prawo” 1972, nr 6.

Zoll A., Charakter prawny kary łącznej, [w:] Zagadnienia teorii i nauczania prawa karnego. Kara taczna. Ksiega jubileuszowa Profesor Marii Szewczyk, red. W. Górowski, P. Kardas, T. Sroka, W. Wróbel, Warszawa 2013. 